\title{
The role of coccoliths in protecting Emiliania huxleyi against stressful light and UV radiation
}

\author{
Juntian Xu ${ }^{1,2}$, Lennart T. Bach ${ }^{3}$, Kai G. Schulz ${ }^{3}$, Wenyan Zhao ${ }^{1}$, Kunshan Gao ${ }^{1}$, and Ulf Riebesell ${ }^{3}$ \\ ${ }^{1}$ State Key Laboratory of Marine Environmental Science, Xiamen University, Xiamen, Fujian, 361102 China \\ ${ }^{2}$ Key Laboratory of Marine Biotechnology of Jiangsu Province, Huaihai Institute of Technology, Lianyungang, \\ Jiangsu, 222005 China \\ ${ }^{3}$ GEOMAR Helmholtz Centre for Ocean Research Kiel, Düsternbrooker Weg 20, Kiel, 24105 Germany \\ Correspondence to: Kunshan Gao (ksgao@xmu.edu.cn)
}

Received: 14 April 2016 - Published in Biogeosciences Discuss.: 28 April 2016

Revised: 7 July 2016 - Accepted: 20 July 2016 - Published: 18 August 2016

\begin{abstract}
Coccolithophores are a group of phytoplankton species which cover themselves with small scales (coccoliths) made of calcium carbonate $\left(\mathrm{CaCO}_{3}\right)$. The reason why coccolithophores form these calcite platelets has been a matter of debate for decades but has remained elusive so far. One hypothesis is that they play a role in light or UV protection, especially in surface dwelling species like Emiliania huxleyi, which can tolerate exceptionally high levels of solar radiation. In this study, we tested this hypothesis by culturing a calcified and a naked strain under different light conditions with and without UV radiation. The coccoliths of $E$. huxleyi reduced the transmission of visible radiation (400$700 \mathrm{~nm})$ by $7.5 \%$, that of UV-A $(315-400 \mathrm{~nm})$ by $14.1 \%$ and that of UV-B $(280-315 \mathrm{~nm})$ by $18.4 \%$. Growth rates of the calcified strain (PML B92/11) were about 2 times higher than those of the naked strain (CCMP 2090) under indoor constant light levels in the absence of UV radiation. When exposed to outdoor conditions (fluctuating sunlight with UV radiation), growth rates of calcified cells were almost 3.5 times higher compared to naked cells. Furthermore, the relative electron transport rate was $114 \%$ higher and nonphotochemical quenching (NPQ) was $281 \%$ higher in the calcified compared to the naked strain, implying higher energy transfer associated with higher NPQ in the presence of calcification. When exposed to natural solar radiation including UV radiation, the maximal quantum yield of photosystem II was only slightly reduced in the calcified strain but strongly reduced in the naked strain. Our results reveal an important role of coccoliths in mitigating light and UV stress in E. huxleyi.
\end{abstract}

\section{Introduction}

Coccolithophores are a group of marine phytoplankton species which are able to precipitate $\mathrm{CaCO}_{3}$ in the form of small calcitic scales (coccoliths) surrounding the organic part of the cell. They contribute about $1-10 \%$ to marine primary production (Poulton et al., 2007) and approximately $50 \%$ to pelagic deep-ocean $\mathrm{CaCO}_{3}$ sediments (Broecker and Clark, 2009). Blooms of coccolithophores can cover up to 8 million $\mathrm{km}^{2}$ of the Earth's surface (Moore et al., 2012) and are considered to be important drivers of biogeochemical cycling (Rost and Riebesell, 2004).

Despite intense research on coccolithophore calcification and its biogeochemical relevance during the last decade, it is still an unresolved question why coccolithophores calcify (Young, 1994; Raven and Crawfurd, 2012). One hypothesis is that the layer of coccoliths surrounding the cell (coccosphere) protects the organism from excess light and UV radiation. This notion is supported by the exceptionally high light tolerance of the surface layer dwelling species Emiliania huxleyi (Nanninga and Tyrell, 1996; Ragni et al., 2008; Gao et al., 2009; Loebl et al., 2010).

Physiological studies investigating the light tolerance of E. huxleyi showed that the radiation wavelength matters in this context. The coccosphere does not seem to constitute a protection against very high intensities of photosynthetically active radiation (PAR) since noncalcifying $E$. huxleyi cells are as resistant to photoinhibition as their calcifying counterparts (Nanninga and Tyrrell, 1996). This is in clear contrast to the influence of stressful ultraviolet radiation (UVR) on 
the cells where results from different physiological experiments support a protective role of the coccoliths (Gao et al., 2009, 2012; Guan and Gao, 2010). Protection from UVR or high light exposures by coccoliths may either work by physically shading intracellular organelles or by strongly scattering light, which is certainly a feature of coccolithophore blooms (Balch et al., 1996; Voss et al., 1998). The underlying mechanisms, however, are not well understood and warrant further investigations.

UVR strongly contributes to photoinhibition of photosystem II (e.g., Hakala-Yatkin et al., 2010) and effectively inhibits repair processes (Ragni et al., 2008). Therefore, it is likely that the coccoliths protect PSII repair from UV inhibition. In this study we explore in more detail how different PAR and UV radiation $(280-400 \mathrm{~nm})$ treatments affect calcified and naked E. huxleyi cells. Specifically we address the question of whether the coccosphere of E. huxleyi helps the cells to withstand stressful levels of PAR and/or UV radiation and whether calcification influences photochemical performance.

\section{Materials and methods}

\subsection{Materials and pre-culture conditions}

Calcified E. huxleyi (PML B92/11 isolated in the Raunefjord area, Bergen, Norway) and naked cells (CCMP 2090 isolated in the South Pacific) were used in the experiments. Both strains were grown in triplicate cultures $(300 \mathrm{~mL}$ square glass bottles) at $15^{\circ} \mathrm{C}$ in $0.2 \mu \mathrm{m}$ filtered natural seawater (gathered from the Bay of Biscay) at a photon flux density of $500 \mu$ mol photons $\mathrm{m}^{-2} \mathrm{~s}^{-1}$ on a $16-8$ light-dark cycle. The natural seawater medium was enriched with $64 \mu \mathrm{mol} \mathrm{L}^{-1}$ nitrate, $4 \mu \mathrm{mol} \mathrm{L}^{-1}$ phosphate, $f / 8$ concentrations of a trace metal and vitamin mixture (Guillard and Ryther, 1962), and $10 \mathrm{nmol} \mathrm{kg}^{-1}$ selenium. Pre-cultures and experimental incubations in semicontinuously diluted batch cultures (> eight generations) ensured exponential growth throughout the experiment.

\subsection{Experimental setup}

\subsubsection{Indoor growth experiments}

After pre-culture for at least eight generations, the cells of calcified and naked strains were inoculated in the same glass bottles of $300 \mathrm{~mL}$ and cultured under the same conditions as pre-cultures, maintaining the cell concentrations at exponen-

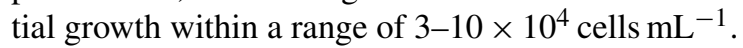

\subsubsection{Outdoor growth experiments}

Following the indoor growth experiment, the cells were transferred into quartz tubes $(100 \mathrm{~mL})$ for the outdoor growth experiment and were exposed to natural solar radiation at the pier of GEOMAR. The cultures were maintained outside in a flow-through water tank, where the seawater temperature was maintained within a range of $14-16^{\circ} \mathrm{C}$. After the cells had acclimated for 7 days under the solar radiation, aliquots of the cell cultures were transferred to new quartz tubes filled with fresh medium before measurements were taken. For the outdoor cultures, the cells received $60 \%$ full-spectrum solar radiation (the quartz tubes were wrapped with neutral density screens). The daytime average intensities (from 07:00 to 17:00) of PAR, UV-A and UV-B which the cells received during the outdoor experiment were about $260 \mu \mathrm{mol}$ photons $\mathrm{m}^{-2} \mathrm{~s}^{-1}$ (about $53 \mathrm{~W} \mathrm{~m}^{-2}$ ), 12.4 and $0.34 \mathrm{~W} \mathrm{~m}^{-2}$, respectively.

\subsubsection{Short-term incubation experiments}

Short-term incubation experiments were carried out to test UV effects around noontime on a cloudy day and sunny day. Three different radiation treatments were implemented as follows: (1) cells in uncovered quartz tubes, receiving the full spectrum of solar radiation (above $280 \mathrm{~nm}$, PAR+UV$\mathrm{A}+\mathrm{UV}-\mathrm{B}$ (PAB) treatment); (2) cells in quartz tubes covered with Folex 320 (Montagefolie, Nr. 10155099, Folex, Dreieich, Germany), exposed to UV-A and PAR (above $320 \mathrm{~nm}$, PAR+UV-A (PA) treatment); and (3) cells receiving only PAR ( $P$ treatment) in quartz tubes covered with Ultraphan film 395 (UV Opak, Digefra, Munich, Germany). The transmission spectra of the quartz tubes and the cutoff foils are given by Zheng and Gao (2009). A time-course experiment was also conducted around noon under full solar spectrum conditions.

\subsection{Absorptivity of coccoliths}

We examined absorption spectra of the cells with or without coccoliths to get an indication of how much light and/or UV are blocked by the coccosphere. Therefore, calcified cells, decalcified cells and cells of the naked strain were filtered onto Whatman GF/F glass fiber filters $(25 \mathrm{~mm})$ and then were subsequently placed at the window near the detector of a double-beam UV-VIS-NIR spectrophotometer (PerkinElmer, Lambda950, USA) which can obtain the absolute absorbance of coccoliths based on the recaptured scattered light. The absorption of the GF/F filter was corrected with a control filter which was soaked with particle-free culture medium (Kishino et al., 1985).

\subsection{Growth measurement}

Cell densities were measured during a period of 7 days with a particle counter (Coulter Z1, Beckman). The specific growth rate was calculated as $\mu\left(\mathrm{d}^{-1}\right)=\left(\operatorname{lnN}_{t}-\ln N_{0}\right) / t$, where $N_{0}$ and $N_{t}$ represent the cell concentrations at the beginning and the end of the incubations and $t$ is the incubation time in days. 


\subsection{Chlorophyll fluorescence measurement}

Parameters of in vivo induced chlorophyll $a$ fluorescence of photosystem II were estimated by a phyto-pulse amplitudemodulated fluorometer (Phyto-PAM, Walz). The maximum quantum yield of PSII $\left(F_{v} / F_{\mathrm{m}}\right)$ was calculated as $F_{v} / F_{\mathrm{m}}=$ $\left(F_{\mathrm{m}}-F_{o}\right) / F_{\mathrm{m}}$; where $F_{o}$ is the basal fluorescence under a measuring light of $0.2 \mu \mathrm{mol}$ photons $\mathrm{m}^{-2} \mathrm{~s}^{-1}$ and $F_{\mathrm{m}}$ is the maximal fluorescence measured with a saturating light pulse of $5000 \mu \mathrm{mol}$ photons $\mathrm{m}^{-2} \mathrm{~s}^{-1}(0.8 \mathrm{~s})$ in dark-adapted (15 min) cells.

In order to compare the transmission of the same strain with or without coccoliths and to relate this to that of the naked strain, the calcified strain was decalcified with $\mathrm{HCl}\left(1 \mathrm{~mol} \mathrm{~L}^{-1}\right.$, the final concentration is $\left.0.01 \mathrm{~mol} \mathrm{~L}^{-1}\right)$ for $10 \mathrm{~s}$ and subsequent recovery of the $\mathrm{pH}$ with equimolar amounts of $\mathrm{NaOH}$. Photochemical performance was measured for dark-adapted $(15 \mathrm{~min})$ cells in calcified, decalcified and naked cells. Decalcified cells revealed $F_{v} / F_{\mathrm{m}}$ values similar to those obtained prior to decalcification. The actinic light levels were set to 533, 1077 and $2130 \mu \mathrm{mol}$ photons $\mathrm{m}^{-2} \mathrm{~s}^{-1}$, respectively (growth light, saturated light and oversaturated light). Non-photochemical quenching (NPQ) was calculated as $\mathrm{NPQ}=\left(F_{\mathrm{m}}-F_{\mathrm{m}}^{\prime}\right) / F_{\mathrm{m}}^{\prime}$, where $F_{\mathrm{m}}$ was the maximum fluorescence yield after dark adaptation and $F_{\mathrm{m}}^{\prime}$ the maximum fluorescence yield under the actinic light levels.

To determine rapid light curves (RLCs; electron transport rate vs. light), the cells were exposed to 10 different PAR levels in sequence $(87,140,263,382,449,611,778,993,1195$ and $1391 \mu \mathrm{mol}$ photons $\mathrm{m}^{-2} \mathrm{~s}^{-1}$ ), each of which lasted for $20 \mathrm{~s}$. The relative electron transport rate (rETR) was assessed as $\mathrm{rETR}=$ Yield $\times 0.5 \times \mathrm{PFD}$, where the yield represents the effective quantum yield of PSII $\left(F_{v}^{\prime} / F_{\mathrm{m}}^{\prime}\right)$; the coefficient 0.5 takes into account that roughly $50 \%$ of all absorbed quanta reach PSII; and PFD is the photon flux density of the actinic light $\left(\mu \mathrm{mol} \mathrm{m} \mathrm{m}^{-2} \mathrm{~s}^{-1}\right)$ (Genty et al., 1989).

To examine immediate photochemical responses of the cells to UV radiation, the cells were exposed to the three different solar radiations (see above) for $60 \mathrm{~min}$ during noontime under natural solar radiation. The effective quantum yield was calculated as $F_{v}^{\prime} / F_{\mathrm{m}}^{\prime}=\left(F_{\mathrm{m}}^{\prime}-F_{t}\right) / F_{\mathrm{m}}^{\prime}$, where $F_{\mathrm{m}}^{\prime}$ and $F_{t}$ are the maximal fluorescence and steady-state fluorescence in the light-adapted cells, respectively.

\subsection{Measurement of solar irradiances}

Solar PAR was measured using a Quantum Scalar Laboratory Irradiance Sensor (QSL-2100/2101, Biospherical Instruments, San Diego, USA). The measured values were recorded every $10 \mathrm{~s}$ and saved on a computer. Solar UVA and UV-B radiation were measured with a radiometer (PMA 2100 Solar Light Co., Glenside, USA); the mean irradiances of solar UV-A and UV-B during the experimental

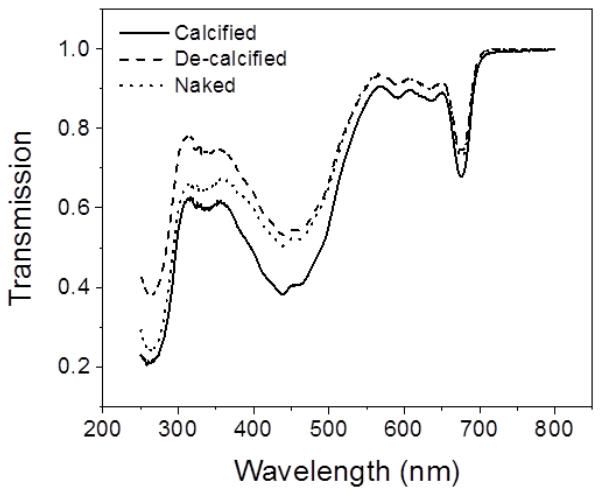

Figure 1. Transmission spectra of cells with (calcified strain) and without (calcified strain with coccoliths removed artificially, decalcified strain) coccolith cover and naked cells of Emiliania huxleyi.

periods were confirmed according to the ratios of UV-A/UV$\mathrm{B}$ to PAR at the experimental location.

\subsection{Statistics}

The data were expressed as the means \pm standard deviation (SD). The statistical significance of the data was tested with software of Origin 9.0 (one-way ANOVA, Tukey's post hoc test). A confidence level of $95 \%$ was used in all analyses.

\section{Results}

The coccolith layer of $E$. huxleyi absorbed both visible and UV radiation. It reduced the transmission of visible radiation $(400-700 \mathrm{~nm})$ by $7.5 \%$, that of UV-A $(315-400 \mathrm{~nm})$ by $14.1 \%$ and that of UV-B by $18.4 \%(280-315 \mathrm{~nm})$ relative to decalcified cells and by $6.5 \%$ for PAR, $6.6 \%$ for UV-A and $5.1 \%$ for UV-B, relative to naked cells (Fig. 1). The specific growth rate of calcifying E. huxleyi strain (PML B92/11) was about 2 times higher than that of the naked strain (CCMP 2090) $(P<0.05)$ when grown at $500 \mu \mathrm{mol}$ photons $\mathrm{m}^{-2} \mathrm{~s}^{-1}$ of PAR under indoor conditions (Fig. 2a). Growth rates of both strains were significantly $(P<0.05)$ reduced when the cells were transferred outdoors and exposed to natural solar radiation. However, under outdoor conditions, growth rates of calcified cells were 3.5 times higher than those of the naked cells, indicating that the latter was more harmed by the solar exposure than the former (Fig. 2a). The cell diameter was not significantly different in the calcified cells between the indoor and outdoor conditions $(P>0.05)$, but an $18 \%$ increase was found in the naked cells after they had grown under outdoor conditions for 7 days $(P<0.05)$ (Fig. 2b). The maximal quantum yield $\left(F_{v} / F_{\mathrm{m}}\right)$ decreased when the cells were transferred from indoor to the outdoor conditions, reflecting a harmful effect of solar radiation. The decrease in $F_{v} / F_{\mathrm{m}}$, however, was much more pronounced in the naked cells (27\%) compared to calcified cells (11\%) (Fig. 2c). 

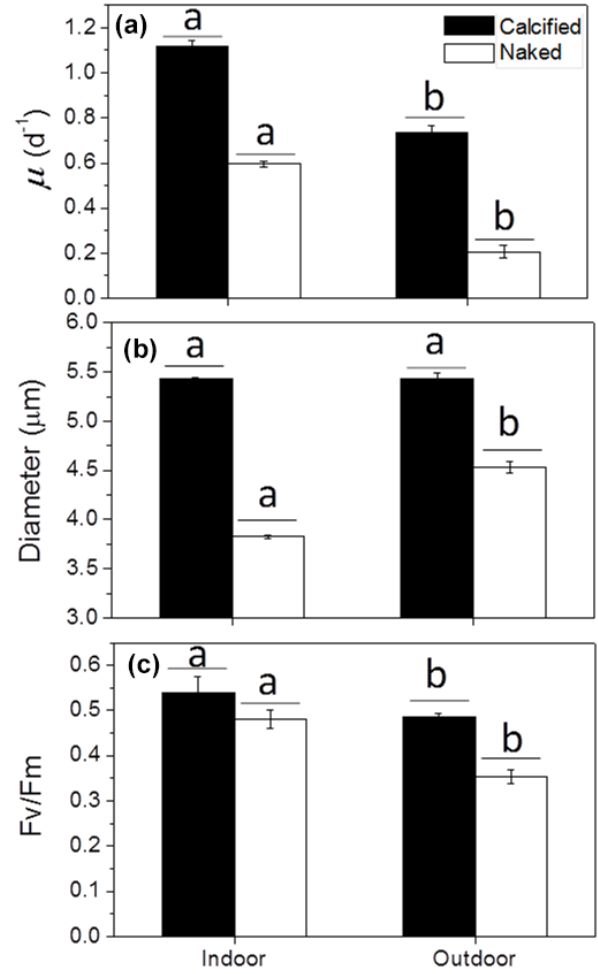

Figure 2. The specific growth rate $(\mu)(\mathbf{a})$, diameter (b) and maximum quantum yield (c) of PSII $\left(F_{v} / F_{\mathrm{m}}\right)$ of the calcified and naked cells of $E$. huxleyi grown in indoor and outdoor conditions. Different letters represent significant differences between the indoor and outdoor experiments. Different horizontal lines represent significant differences between the different strains.

Table 1. Photosynthetic parameters of relative electron transport rate (Fig. 3) as a function of PAR; different letters represent significant differences $(P<0.05)$ among the calcified, decalcified and naked cells.

\begin{tabular}{llll}
\hline & Calcified & Decalcified & Naked \\
\hline$\alpha$ & $0.23 \pm 0.02^{\mathrm{a}}$ & $0.20 \pm 0.01^{\mathrm{a}}$ & $0.17 \pm 0.02^{\mathrm{b}}$ \\
rETR $_{\max }$ & $90.6 \pm 9.0^{\mathrm{a}}$ & $73.5 \pm 3.5^{\mathrm{b}}$ & $42.3 \pm 8.5^{\mathrm{c}}$ \\
$I_{k}$ & $1010.8 \pm 95.0^{\mathrm{a}}$ & $986.3 \pm 27.4^{\mathrm{a}}$ & $621.8 \pm 111.1^{\mathrm{b}}$ \\
\hline
\end{tabular}

Calcified cells had a significantly higher apparent light use efficiency $(\alpha)$, maximal electron transport rate $\left(\mathrm{rETR}_{\max }\right)$ and light saturation parameters $\left(I_{k}\right)$ compared to naked cells. The decalcified cells of the calcified strain showed a remarkable decrease in $\mathrm{rETR}_{\max }(P<0.05)$, and alpha and $I_{k}$ also decreased but not statistically significantly (Fig. 3, Table 1). Increased actinic light levels (acclimating light during the fluorescence measurement) led to higher NPQ in both the calcified and naked strain (Fig. 4). Furthermore, calcified cells showed higher NPQ values compared to naked cells $(p<0.05)$.

When exposed to full-spectrum solar radiation, the quantum yield of calcified cells showed no significant change dur-

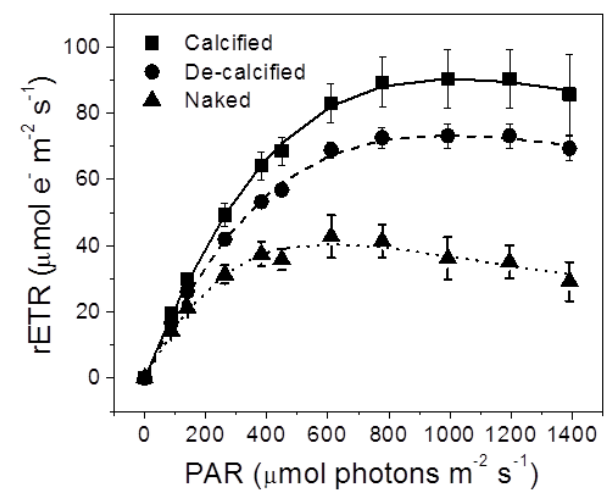

Figure 3. The relative electron rate (rETR) of calcified, decalcified and naked cells of $E$. huxleyi grown under indoor conditions as function of PAR. The cells were grown for 12-22 generations under $500 \mu \mathrm{mol}$ photons $\mathrm{m}^{-2} \mathrm{~s}^{-1}$ of PAR.

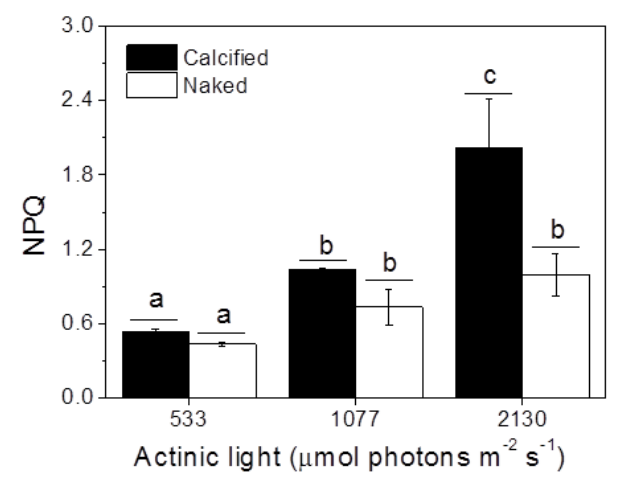

Figure 4. The non-photochemical quenching (NPQ) of calcified and naked cells of E. huxleyi grown under indoor conditions. Different letters represent significant differences among the light levels. Different horizontal lines represent significant differences among the different type cells.

ing the first $30 \mathrm{~min}(P>0.05)$. After $30 \mathrm{~min}$, the quantum yield quickly dropped from about 0.35 to 0.22 for $\sim 20 \mathrm{~min}$ $(P<0.05)$, followed by a slight recovery in the last $25 \mathrm{~min}$. A similar trend was observed in the decalcified cells, with the key difference that the sharp decrease already happened during the first $10 \mathrm{~min}$. The quantum yield of the naked cells decreased constantly for the first $50 \mathrm{~min}$ and remained at the low level thereafter (Fig. 5).

No effect of the radiation treatment $(P, \mathrm{PA}$ and $\mathrm{PAB}$ radiation) on the quantum yield of calcified cells was observed after the cells grown under indoor conditions were transferred to outdoor solar radiation for $1 \mathrm{~h}$ exposure (very cloudy day; average PAR, UV-A and UV-B were $481 \mu \mathrm{mol}$ photons $\mathrm{m}^{-2} \mathrm{~s}^{-1}, 22.1$ and $0.7 \mathrm{~W} \mathrm{~m}^{-2}$, respectively) $(P>0.05)$. The quantum yield was significantly higher in the naked cells, however, when they were exposed to UV-A radiation (PA vs. $P$ treatment, $P<0.05$; Fig. 6 a). 


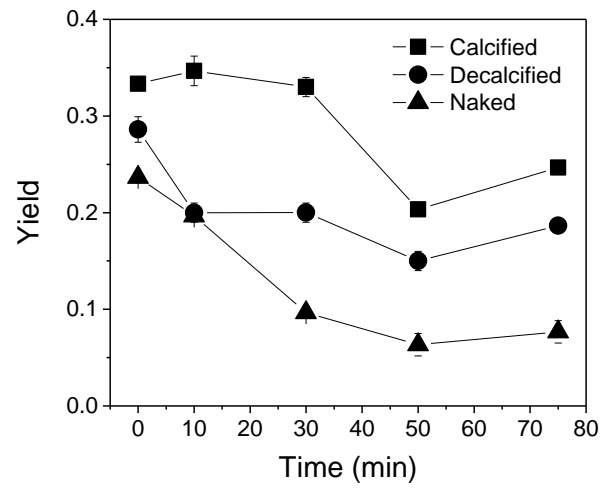

Figure 5. The time course of quantum yield of calcified, decalcified and naked cells of E. huxleyi under full-spectrum solar radiation (noontime, average PAR, UV-A and UV-B were $1082 \mu$ mol photons $\mathrm{m}^{-2} \mathrm{~s}^{-1}, 48.1$ and $1.6 \mathrm{~W} \mathrm{~m}^{-2}$, respectively).

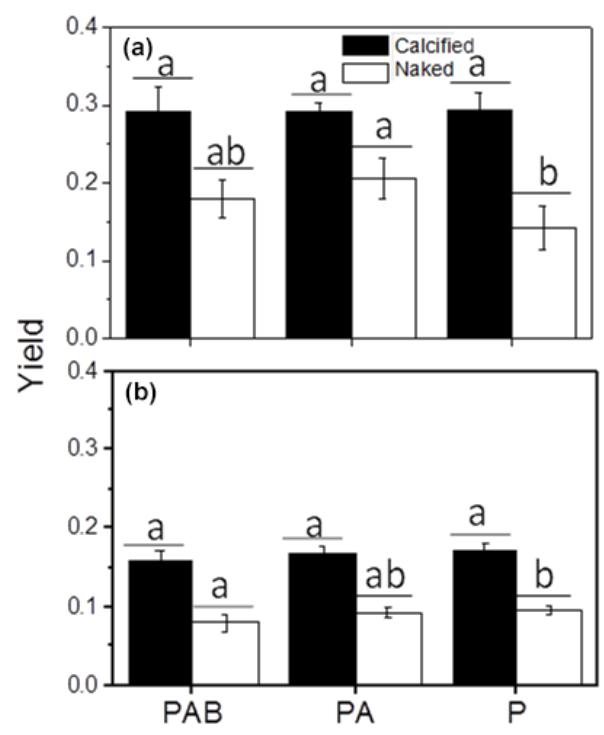

Figure 6. The change in quantum yield of the calcified and naked cells of E. huxleyi when transferred from indoor to outdoor conditions, being exposed to PAR alone $(P)$, PAR+UV-A (PA) and $\mathrm{PAR}+\mathrm{UV}-\mathrm{A}+\mathrm{UV}-\mathrm{B}(\mathrm{PAB})$ for $60 \mathrm{~min}$ at around noontime. Panel (a): measured on a cloudy day (average PAR, UV-A and UV-B were $481 \mu \mathrm{mol}$ photons $\mathrm{m}^{-2} \mathrm{~s}^{-1}, 22.1$ and $0.7 \mathrm{~W} \mathrm{~m}^{-2}$, respectively); panel (b): measured on a sunny day (average PAR, UV-A and UV$\mathrm{B}$ were $1605 \mu \mathrm{mol}$ photons $\mathrm{m}^{-2} \mathrm{~s}^{-1}, 69$ and $2.4 \mathrm{~W} \mathrm{~m}^{-2}$, respectively). Different letters represent significant differences among the light treatments. Different horizontal lines represent significant differences between the different strains.

Similar responses were observed when the same test was done on a sunny day with an average PAR, UV-A and UV$\mathrm{B}$ of $1605 \mu \mathrm{mol}$ photons $\mathrm{m}^{-2} \mathrm{~s}^{-1}$ and 69 and $2.4 \mathrm{~W} \mathrm{~m}^{-2}$, respectively. Here, the quantum yield of the calcified cells showed no significant difference between the different light treatments, but it decreased significantly under the PAB treat- ment compared to $\mathrm{P}$ treatments in the naked cells $(P<0.05)$ (Fig. 6b).

\section{Discussion}

Various hypotheses were proposed for the possible functions of coccoliths, but none of them is supported by sufficient evidence (Young, 1994; Raven and Crawfurd, 2012). One important function of coccoliths for surface-dwelling species such as E. huxleyi could be the protection against high photon flux densities, especially UV radiation (Berge, 1962; Young, 1994; Gao et al., 2009)

Some of our results support this hypothesis. The growth rate of the calcified cells of $E$. huxleyi grown under indoor conditions was about 2 times higher than that of naked cells. This difference came out even more strongly, with growth rates 3.5 times higher in calcified versus naked cells, when the cells were exposed to full-spectrum solar radiation (Fig. 2a). This could potentially be attributed to the screening of PAR, UV-A and UV-B by coccoliths. Although the daytime PAR of solar radiation was reduced to about half of the light level of the indoor test, noontime PAR levels were higher than $500 \mu \mathrm{mol}$ photons $\mathrm{m}^{-2} \mathrm{~s}^{-1}$, and the presence of UV could lead to more harm to the naked cells. Light protection by coccoliths is further supported by the $F_{v} / F_{\mathrm{m}}$ measurements. The maximum photochemical efficiency of PSII was only slightly reduced in calcified cells but significantly decreased in naked cells when they were exposed to natural solar PAR and UV radiation (Fig. 2c). Furthermore, the photochemical performance of decalcified cells decreased significantly faster and more strongly with time compared to calcified cells (Fig. 5).

The diameter of calcified cells did not significantly change when they were exposed to the full spectrum of solar radiation. The diameter of the naked cells, however, increased significantly (Fig. 2b). Perhaps, the naked cells experienced more DNA damage and so did not enter the $S$ phase regularly (Buma et al., 2000). Alternatively, it may reflect a strategy to acclimatize to stressful solar UV radiation since it is well known that smaller cells are usually more sensitive to UV than their larger counterparts (Garcia-Pichel, 1994; Laurion and Vincent, 1998). Some field and laboratory studies showed increased cell size with increased UV exposure (Buma et al., 2000), which can be interpreted as an adaptive or acclimation mechanism for protecting the cells against UV radiation. Furthermore, the naked cells might also employ other strategies, such as synthesizing UV screening compounds to ameliorate UV stress, because the naked strain had a lower UV transmittance than the decalcified strain.

Several studies found that coccoliths do not protect E. huxleyi from excess PAR (Nanninga and Tyrrell, 1996; Houdan et al., 2005; Trimborn et al., 2007). However, UV radiation was not considered in these experiments. Our results showed that the naked cells were more sensitive to full-spectrum 
solar radiation than calcified cells, and even in the same strain, the photochemical performance of decalcified cells decreased significantly when comparing the calcified cells. This suggests that coccoliths efficiently protect the cells from solar UV radiation.

On the other hand, E. huxleyi appears to be more sensitive to UV-B irradiances than other phytoplankton species, and its growth rate and physiological performances were highly inhibited by UV radiation (Peletier et al., 1996; Buma et al., 2000; Xu et al., 2011). However, competition tests for community changes are rare, and longer-term experiments with less extreme UVR would be more ecologically and evolutionarily relevant (Raven and Crawfurd, 2012). In our work, UVR had no significant effect on the quantum yield of calcified cells regardless of high- or low-light conditions but it showed inhibition in naked cells when they were exposed to high-solar light (Fig. 6a, b). This provides further evidence for protection by coccoliths against UV radiation.

On the cloudy day, no significant difference was observed among the treatments for the calcified cells; on the sunny day, under the fluctuating light (data not shown) calcified cells manage to refurbish damage to their photosynthetic apparatus by balancing damage and repair (Gao et al., 2007; Ragni et al., 2008; Loebl et al., 2010). For the naked cells, on the other hand, UV damage was not effectively repaired, leading to the observed negative effect on photosynthetic performance.

It has to be noted that our experimental data are based on only two strains of a naked and calcified E. huxleyi. However, similar trends in photophysiology between naked and decalcified cells in comparison to calcified cells suggest that the coccoliths of E. huxleyi play an important role in protecting this species against harmful solar radiation, especially UVA and UV-B. Furthermore, the reported absence of photoinhibition in this alga at high light levels also appears to be connected to the coccosphere of E. huxleyi or its calcification process. In view of ongoing ocean change, the projected shoaling of the upper mixed layer (UML) caused by global warming and progressive ocean acidification that reduces the thickness or the number of coccoliths per cell (Gao et al., 2009; De Bodt et al., 2010) could reduce E. huxleyi growth rates within the UML due to increased UVR exposure.

\section{The Supplement related to this article is available online at doi:10.5194/bg-13-4637-2016-supplement.}

Acknowledgements. This study was supported by the National Natural Science Foundation (41430967; 41476097; 41120164007), the State Oceanic Administration (National Programme on Global Change and Air-Sea Interaction, GASI-03-01-02-04), the Joint project of National Natural Science Foundation of China and Shandong province (no. U1406403) and the Strategic Priority Research Program of the Chinese Academy of
Sciences (no. XDA1102030204). The visit of Kunshan Gao to Kiel was supported by DAAD. Kai G. Schulz is the recipient of an Australian Research Council Future Fellowship (FT120100384).

Edited by: T. Treude

Reviewed by: D. Campbell and one anonymous referee

\section{References}

Balch W. M., Kilpatrick, K. A., and Trees, E. E.: The 1991 coccolithophore bloom in the central North Atlantic. 1. Optical propertiesand factors affecting their distribution, Limnol. Oceanogr., 41, 1669-1683, 1996.

Berge, G.: Discoloration of the sea due to Coccolithus huxleyi "bloom", Sarsia, 6, 27-40, 1962.

Broecker, W. and Clark, E.: Ratio of coccolith $\mathrm{CaCO}_{3}$ to foraminifera $\mathrm{CaCO}_{3}$ in late Holocene deeper-sea sediments, Paleoceanography, 24, PA3205, doi:10.1029/2009PA001731, 2009.

Buma, A. G. J., van Oijen, T., van de Poll, W., Veldhuis, M. J. W., and Gieskes, W. W. C.: The sensitivity of Emiliania huxleyi (Prymnesiophyceae) to ultraviolet-B radiation, J. Phycol., 36, 296-303, 2000.

De Bodt, C., Van Oostende, N., Harlay, J., Sabbe, K., and Chou, L.: Individual and interacting effects of $p \mathrm{CO}_{2}$ and temperature on Emiliania huxleyi calcification: study of the calcite production, the coccolith morphology and the coccosphere size, Biogeosciences, 7, 1401-1412, doi:10.5194/bg-7-1401-2010, 2010.

Gao, K., Wu, Y., Li, G., Wu, H., Villafañe, V. E., and Helbling, E. W.: Solar UV radiation drives $\mathrm{CO}_{2}$ fixation in marine phytoplankton: A double-edged sword, Plant Physiol., 144, 54-59, 2007.

Gao, K., Ruan, Z., Villafane, V. E., Gattuiso, J. P., and Helbling, E. W.: Ocean acidification exacerbates the effect of UV radiation on the calcifying phytoplankter Emiliania huxleyi, Limnol. Oceanogr., 54, 1855-1862, 2009.

Gao, K., Helbling, E. W., Häder, D. P., and Hutchins, D. A.: Responses of marine primary producers to interactions between ocean acidification, solar radiation, and warming, Mar. Ecol.Prog. Ser., 470, 167-189, 2012.

Garcia-Pichel, F.: A model for internal self-shading in planktonic organisms and its implications for the usefulness of ultraviolet sunscreens, Limnol. Oceanogr., 39, 1704-1717, 1994.

Genty, B., Briantais, J. M., and Baker, N. R.: The relationship between the quantum yield of photosynthetic electron-transport and quenching of chlorophyll fluorescence, Biochim. Biophys. Acta, 990, 87-92, 1989.

Guan, W. and Gao, K.: Enhanced calcification ameliorates the negative effects of UV radiation on photosynthesis in the calcifying phytoplankter Emiliania huxleyi, Chinese Sci. Bull., 55, 588593, 2010.

Guillard, R. R. and Ryther, J. H.: Studies of marine planktonic diatoms: I. Cyclotella nana hustedt, and Detonula confervacea (cleve) gran, Can. J. Microbiol., 8, 229-239, 1962.

Hakala-Yatkin, M., Mäntysaari, M., Mattila, H., and Tyystjärvi, E.: Contributions of visible and ultraviolet parts of sunlight to photoinhibition, Plant Cell Physiol., 51, 1745-1753, 2010.

Houdan, A., Probert, I., Van Lenning, K., and Lefebvre, S.: Comparison of photosynthetic responses in diploid and haploid life-cycle 
phases of Emiliania huxleyi (Prymnesiophyceae), Mar. Ecol.Prog. Ser., 292, 139-146, 2005.

Kishino, M., Takahashi. M., Okami, N., and Ichimur, S.: Estimation of the spectral absorption coefficients of phytoplankton in the sea, Bull. Mar. Biol., 37, 634-642, 1985.

Laurion, I. and Vincent, W. F.: Cell size versus taxonomic composition as determinants of UV-sensitivity in natural phytoplankton communities, Limnol. Oceanogr., 43, 1774-1779, 1998.

Loebl, M., Cockshutt, A. M., Campbell, D. A., and Finkel, Z. V.: Physiological basis for high resistance to photoinhibition under nitrogen depletion in Emiliania huxleyi, Limnol. Oceanogr., 55, 2150-2160, 2010.

Moore, T. S., Dowell, M. D., and Franz, B. A.: Detection of coccolithophore blooms in ocean color satellite imagery: a generalized approach for use with multiple sensors, Remote Sens. Environ., 117, 249-263, 2012.

Nanninga, H. J. and Tyrrell, T.: Importance of light for the formation of algal blooms by Emiliania huxleyi, Mar. Ecol.-Prog. Ser., 136, 195-203, 1996

Peletier, H., Gieskes, W. W. C., and Buma, A. G. J.: Ultraviolet-B radiation resistance of benthic diatoms isolated from tidal flats in the Dutch Wadden Sea, Mar. Ecol.-Prog. Ser., 135, 163-168, 1996.

Poulton, A. J., Adey, T. R., Balch, W. M., and Holligan, P. M.: Relating coccolithophore calcification rates to phytoplankton community dynamics: regional differences and implications for carbon export, Deep-Sea Res. Pt. II, 54, 538-557, 2007.

Ragni, M., Airs, R. L., Leonardos, N., and Geider, R. J.: Photoinhibition of PSII in Emiliania huxleyi (Haptophyta) under high light stress: the roles of photoacclimation, photoprotection, and photorepair, J. Phycol., 44, 670-683, 2008.
Raven, J. A. and Crawfurd, K.: Environmental controls on coccolithophore calcification, Mar. Ecol.-Prog. Ser., 470, 137-166, 2012.

Rost, B. and Riebesell, U.: Coccolithophores and the biological pump: responses to environmental changes, in: Coccolithophores- from molecular processes to global impact, edited by: Thierstein, H. R. and Young, J. R., Springer, Berlin, 99-125, 2004.

Trimborn, S., Langer, G., and Rost, B.: Effect of varying calcium concentrations and light intensities on calcification and photosynthesis in Emiliania huxleyi, Limnol. Oceanogr., 52, 22852293, 2007.

Voss, K., Balch, W. M., and Kilpatrick, K. A.: Scattering and attenuation properties of Emiliania huxleyi cells and their detached coccoliths, Limnol. Oceanogr., 43, 870-876, 1998.

Xu, K., Gao, K., Villafañe, V. E., and Helbling, E. W.: Photosynthetic responses of Emiliania huxleyi to UV radiation and elevated temperature: roles of calcified coccoliths, Biogeosciences, 8, 1441-1452, doi:10.5194/bg-8-1441-2011, 2011.

Young, J. R.: Functions of coccoliths, in: Coccolithophores, edited by: Winter, A. and Siesser, W. G., Cambridge University Press, Cambridge, 63-82, 1994.

Zheng, Y. and Gao, K.: Impacts of solar UV radiation on the photosynthesis, growth, and UV-absorbing compounds in Gracilaria lemaneiformis (Rhodophyta) grown at different nitrate concentrations, J. Phycol., 45, 314-323, 2009. 